\title{
Diversity and inheritance in cowpea (Vigna unguiculata) on protein and yield components characters
}

\author{
INDAH PURNAMASARI ${ }^{1, \bullet}$, SOBIR ${ }^{2, \bullet \bullet}$, MUHAMAD SYUKUR \\ ${ }^{1}$ Plant Breeding and Biotechnology Program, Department of Agronomy, Faculty of Agriculture, Institut Pertanian Bogor. Jl. Meranti, Darmaga Campus, \\ Bogor16630, West Java, Indonesia. Tel./fax.: +62 251 8629353, `email: indah.namasari@gmail.com \\ ${ }^{2}$ Department of Agronomy, Faculty of Agriculture, Institut Pertanian Bogor. Jl. Meranti, Darmaga Campus, Bogor16630, West Java, Indonesia. Tel./fax.: \\ +62 251 8629353, “vemail: rsobir@yahoo.com
}

Manuscript received: 5 December 2018. Revision accepted: 12 April 2019.

\begin{abstract}
Purnamasari I, Sobir, Syukur M. 2019. Diversity and inheritance in cowpea (Vigna unguiculata) on protein and yield components characters. Biodiversitas 20: 1294-1298. Diallel was a method that can be used to see inheritance and diversity character of plants. The objective of this study has evaluated the inheritance and diversity of the yield component characters and seed protein content. This study used genetic material from five homozygous cowpeas (Vigna unguiculata (L.) Walp) genotypes (KM1, KM2, KM4, KM5, and TG2) and 20 F1. Genotypes were planted using a randomized complete block design with three replications. The character observed were the yield components (weight of 100 seed, number of seeds per pod, number of pods per bunch, number of pods per plant and yield) and seeds protein content. Characters that were influenced by general combining ability (GCA) consist of weight of 100 seeds, number of pods per bunch, number of seeds per pod and seed protein content. The variance of GCA has a greater value than the variance of specific combining ability (SCA). Narrow sense and broad sense heritability values were high category consist of weight 100 seed, number seeds per pod, number pods per bunch and seed protein content. That characters were inherited additively. Characters were influenced by additive gene action and have high diversity make it possible to select in F2 generation using the pedigree selection method.
\end{abstract}

Keywords: Additive, diallel, GCA, heritability, SCA

\section{INTRODUCTION}

Legumes are one food source that has many useful ingredients needed by humans. The most important ingredient in legumes is protein. Protein in legumes is a type of vegetable protein, a source of protein that is contained in plants. Proteins are useful as activators of the immune system for protection against foreign organisms and several other important functions (Fürst 2009). Soybean is a source of vegetable protein that is widely used as a basic ingredient in food products. The protein contained in soybeans is 38 grams of protein per 100 soybean seeds. Soybeans can produce optimally if planted in areas with irradiation of more than 12 hours namely in subtropical countries, so other commodities are needed for soybean substitution to meet vegetable protein needs.

One type of legumes that has the same physical shape as soybeans are cowpea. Cowpea (Vigna unguiculata (L.) Walp) is vegetable beans that are usually harvested before and after physiologically mature. Cowpea pods are longer than soybeans, which causes a very significant difference in the number of seeds per pod. Cowpea contains 22 grams of protein per 100 seeds, so that it has the potential to be increased to be equal or close to the value of soy protein content. Character repairing in plants requires the desired diversity of characters, making it easier in the selection process. The higher the diversity of characters who want to be improved, the selection process will be better and can increase the response to selection value. Increasing diversity in plants can use mutations (Molina 2017; Nair 2014), molecular (Buu and MyMy 2003; Boukar et al. 2016), and crosses (Mbusa et al. 2018; Jean Baptiste 2011).

Crossing is the method most often used to increase diversity and improve quality character of plant. The diallel mating design is most commonly used by plant breeders. The design allows a combination of crosses between all the genotype chosen by considering different characters. In diallel crossing can be known the value of combining ability which gives information to breeders about the actions of genes involved in inheritance of a character and diversity of characters (Hayman 1954; Griffing 1956; Aghao et al. 2010; Daryanto et al. 2010; Syukur et al. 2010; Aisya et al. 2016; Ganefianti et al. 2018). Based on this description, this study was conducted to obtain information about inheritance in cowpea using diallel crossing with a griffing approach to the character of the yield components and protein content of the seeds.

\section{MATERIALS AND METHODS}

Field experiments were conducted at Ponci, Sulawesi Selatan, Indonesia. The line used in this study consist of five homozygous parents (KM1, KM2, KM4, KM5, and TG2) and 20 F1 hybrids. The hybrids 1 and reciprocals were made by the full Diallel cross method. The parents and $\mathrm{F} 1$ were evaluated in a randomized complete block design (RCBD) with three replicates. Each block was 
divided into 25 plots each measuring $0.8 \mathrm{~m}^{2}$. Seedlings were grown at a spacing of $40 \mathrm{~cm} \times 10 \mathrm{~cm}$ inter-row. Parents and F1 were randomly assigned to each block and labeled accordingly. Fertilization was done a week after planting (7 days), fertilizing using Urea $2.5 \mathrm{~kg} \mathrm{ha}^{-1}$, TSP 45 $\mathrm{kg} \mathrm{ha}^{-1}$, and $\mathrm{KCl} 45 \mathrm{~kg} \mathrm{ha}^{-1}$. In the flowering stage, the experimental plot was sprayed with lambda-cyhalothrin 2 ml 1-1 insecticide once a week to suppress fruit borers (Indiana 2007) and sprayed Nissuron 50 EC to control aphid fleas.

\section{Data collect}

The data collected on the yield characters consisted of weight of 100 seeds were count 100 seed dried per plot, number of seeds per pod were counted 1 pod per bunch, number of pods per bunch were count number of pod per bunch in sample plants, number of pods per plant were count number of pods per plant in sample plants, yield per plant were count all of the dried seeds in sample plants and seed protein content were analysis used Kjeldahl analysis. each yield character collected 10 sample per plot totally 75 plot consist parent, f1 and f1r while seed protein content using 45 samples consist of parents and f1. Data of character results were analyzed using DiallelGriffing Method 1 while seed protein content was analyzed using Diallel Griffing Method 2.

\section{Data analyses}

Analysis variance (ANOVA) and genetic analysis weight of 100 seed, number of seed per pod, number of pods per bunch, number of pods per plant, yield per plant, and seed protein content were analyzed using AGD-R v4.0. Analysis variance using probability $1 \%$ for highly significant and 5\% for significant. DiallelGriffing's Method 1 (Parents, F1, Reciprocal F1 hybrid) and model 2 (random model) were used to estimate the general combining ability (GCA), specific combining ability (SCA) and reciprocals effect for yield component (Sing and Chaudhary 1979). DiallelGriffing's Method 2 (Parents, F1, excluding reciprocal F1 crosses) and model 2 (random model) were used to estimate the general combining ability (GCA) and specific combining ability (SCA) for seed protein content.

$$
\begin{aligned}
\mathrm{MS}_{\mathrm{E}}{ }^{\prime} & =\frac{\mathrm{MS}_{\mathrm{E}}}{\mathrm{r}}, \text { with } \mathrm{r}=\text { block } \\
\sigma_{\mathrm{E}}^{2} & =\mathrm{MS}_{\mathrm{E}} \\
\sigma_{\mathrm{g}}^{2} & =\frac{1}{2 \mathrm{p}}\left[\mathrm{MS_{ \textrm {g } }}-\frac{\mathrm{MS}{{ }_{\mathrm{E}}}_{\mathrm{E}}+\mathrm{p}(\mathrm{p}-1) M S_{\mathrm{s}}}{\mathrm{p}^{2}-\mathrm{p}+1}\right] \\
\sigma_{\mathrm{S}}^{2} & =\frac{\mathrm{p}^{2}}{2\left(\mathrm{p}^{2}-\mathrm{p}+1\right)}\left[\mathrm{MS}_{\mathrm{s}}-\mathrm{MS}_{\mathrm{E}}\right] \\
\sigma_{\mathrm{r}}^{2} & =\frac{1}{2}\left[\mathrm{MS}_{\mathrm{r}}-\mathrm{MS}_{\mathrm{E}}^{\prime}\right]
\end{aligned}
$$

Additive variance and dominant variance were obtained from general combining ability (GCA) and specific combining ability (SCA) if all of diallel assumptions were covered (Griffing 1956);

$$
\begin{aligned}
& \sigma^{2}{ }_{\mathrm{A}}=2 \sigma^{2} \mathrm{~g} \\
& \sigma_{\mathrm{s}}^{2}=\sigma^{2}{ }_{\mathrm{D}}
\end{aligned}
$$

\begin{tabular}{|c|c|c|c|}
\hline $\begin{array}{c}\text { Source of } \\
\text { variation }\end{array}$ & $\begin{array}{c}\text { Degree of } \\
\text { freedom }\end{array}$ & $\begin{array}{c}\text { Mean } \\
\text { square }\end{array}$ & $\begin{array}{c}\text { Expected } \\
\text { mean square }\end{array}$ \\
\hline Replication & $\mathrm{r}-1$ & $\mathrm{MS}_{\mathrm{R}}$ & \\
\hline Genotype & $\mathrm{v}-1$ & $\mathrm{MS}_{\mathrm{G}}$ & $\sigma^{2} \mathrm{E}+\mathrm{r} \sigma^{2} \mathrm{G}$ \\
\hline GCA & $(\mathrm{p}-1)$ & $\mathrm{MS}_{\mathrm{g}}$ & $\sigma^{2} E+\frac{2\left(p^{2}-p+1\right)}{p^{2}} \sigma^{2} s+2 p \sigma^{2} g$ \\
\hline SCA & $(\mathrm{p}-1)$ & $\mathrm{MS}_{\mathrm{s}}$ & $\sigma^{2} \mathrm{E}+\frac{2\left(\mathrm{p}^{2}-\mathrm{p}+1\right)}{\mathrm{p}^{2}} \sigma_{\mathrm{s}}^{2}$ \\
\hline $\begin{array}{l}\text { Reciprocal } \\
\text { Error }\end{array}$ & $\begin{array}{l}\frac{1}{2} \mathrm{p}(\mathrm{p}-1) \\
(\mathrm{r}-1)(\mathrm{v}-1)\end{array}$ & $\begin{array}{l}\mathrm{MS}_{\mathrm{r}} \\
\mathrm{MSE}_{\mathrm{E}}\end{array}$ & $\begin{array}{l}\sigma^{2} \mathrm{E}+2 \sigma^{2} \mathrm{r} \\
\sigma^{2} \mathrm{E}\end{array}$ \\
\hline
\end{tabular}

General combining ability (GCA), specific combining ability (SCA), and variance of protein content assumptions were using diallel method 2.
Table 1. Anova combining ability Diallel Method 1 with references to Sing and Chaudhary (1979).

Table 2. Anova combining ability Diallel Method 2 with references to Sing and Chaudhary (1979)

\begin{tabular}{llll}
$\begin{array}{llll}\text { Source of } \\
\text { variation }\end{array}$ & $\begin{array}{l}\text { Degree of } \\
\text { freedom }\end{array}$ & $\begin{array}{l}\text { Mean } \\
\text { square }\end{array}$ & $\begin{array}{l}\text { Expected } \\
\text { mean square }\end{array}$ \\
\cline { 1 - 2 } Replication & $\mathrm{r}-1$ & $\mathrm{MS}_{\mathrm{R}}$ & \\
Genotype & $\mathrm{v}-1$ & $\mathrm{MS}$ & $\sigma_{\mathrm{G}}^{2} \mathrm{E}+\sigma^{2} \mathrm{G}$ \\
GCA & $(\mathrm{p}-1)$ & $\mathrm{MS}$ & $\sigma_{\mathrm{E}}^{2}+\sigma^{2}{ }_{\mathrm{s}}+(\mathrm{p}+2) \mathrm{p} \sigma_{\mathrm{g}}^{2}$ \\
SCA & $(\mathrm{p}-1)$ & $\mathrm{MSs}$ & $\sigma 2 \mathrm{E}+\sigma 2 \mathrm{~s}$ \\
Error & $(\mathrm{r}-1)(\mathrm{v}-1)$ & $\mathrm{MS} \mathrm{S}_{\mathrm{E}}$ & $\sigma_{\mathrm{E}}^{2}$ \\
\hline
\end{tabular}

$$
\begin{aligned}
\mathrm{MS}_{\mathrm{E}} & =\frac{\mathrm{MS}_{\mathrm{E}}}{\mathrm{rs}}, \text { with } \mathrm{r}=\text { block dan } \mathrm{s}=\text { sample } \\
\sigma_{\mathrm{E}}^{2} & =\mathrm{MS}_{\mathrm{E}} \\
\sigma_{\mathrm{g}}^{2} & =\frac{1}{(\mathrm{p}+2)}\left[\mathrm{MS}_{\mathrm{g}}-\mathrm{MS}_{\mathrm{S}}\right] \\
\sigma_{\mathrm{s}}^{2} & =\left[\mathrm{MS}_{\mathrm{S}}-\mathrm{MS}_{\mathrm{E}}^{\prime}\right]
\end{aligned}
$$

Additive variance and dominant variance were obtained from general combining ability (GCA) and specific combining ability (SCA) if all of diallel assumptions were covered (Griffing 1956);

$$
\begin{aligned}
\sigma^{2}{ }_{\mathrm{A}} & =2 \sigma^{2} \mathrm{~g} \\
\sigma^{2}{ }_{\mathrm{S}} & =\sigma^{2}{ }_{\mathrm{D}}
\end{aligned}
$$

Broad-sense heritability $\left(\mathrm{h}^{2}\right.$ bs $)$ dan narrow-sense heritability $\left(\mathrm{h}^{2} \mathrm{~ns}\right)$ were obtained from Diallel analysis method 1 and method 2 (Sing dan Chaudhary 1979).

$$
\begin{aligned}
\mathrm{h}^{2} \mathrm{bs} & =\frac{2 \sigma^{2} \mathrm{GCA}+\sigma^{2} \mathrm{SCA}}{2 \sigma^{2} \mathrm{GCA}+\sigma^{2} \mathrm{SCA}+\sigma^{2} \mathrm{E}} \\
\mathrm{h}^{2} \mathrm{~ns} & =\frac{2 \sigma^{2} \mathrm{GCA}}{2 \sigma^{2} \mathrm{GCA}+\sigma^{2} \mathrm{SCA}+\sigma^{2} \mathrm{E}}
\end{aligned}
$$

\section{RESULT AND DISCUSSION}

\section{Combining ability \\ Yield component}

Yield component consists of 100 seeds weight, number of seeds per pod, number of pods per bunch, number of pods per plant, and yield per plant (Table 3 ). In the analysis of variance, it was found that the general combining ability (GCA) the weight of 100 seeds was significant at 0.01 level, whereas in peanuts (Neya et al. 2017) the results showed that the weight of 100 seeds has been significant at specific combining ability (SCA). The number of seeds per pod was significant at the 0.01 level different from the results of the study by Dahosa and Alika (2013), the number of seeds per pod has been significant value, in 
general, combining ability (GCA) and specific combining ability (SCA) while in peanut (Jogloy et al. 2005), the yield character pods, seed yield, and weight of 100 seeds have been significant in general combining ability (GCA). The number of pods per bunch was significantly 0.05 in the general combining ability (GCA) while the character of the number of pods per plant and yield per plant was not significant in all components of variance, whereas the results obtained by Patel et al. (2010) showed pods per plant was significant in specific combining ability (SCA) and the results obtained Alam (2013) was significant on SCA and GCA in peanuts.

\section{Protein content}

Protein content was significant at the 0.01 level on general combining ability (GCA) while the specific combining ability (SCA) was not significant at the level of 0.05 and 0.01 , which is different from the results of studies on wheat and Indian beans (Dolichous lablab L) (Patil et al. 2013; Al-Naggar 2015) protein content in wheat have been significant at 0.01 level on general combining ability (GCA) and specific combining ability (SCA).

\section{Variance}

Yield component

The yield components included weigh of 100 seeds, number of seeds per pod, number of pods per bunch, number of pods per plant, and yield per plant had a higher GCA value than the SCA value (Table 5). The value of heritability in a broad sense and narrow sense can be obtained from variance values. The heritability values indicate the broad sense heritability and narrow sense heritability on all components of the yield in the high category except yield per plant (Syukur et al. 2010) with a broad sense heritability and narrow sense heritability of weight 100 seed each 0.98 and 0.98 , number of seeds per pod 0.99 and 0.98 , number of pods per bunch 0.91 and 0.90 , number of pods per plant 0.95 and 0.85 , yield per plant 0.89 and 0.45 , according the results of narrow sense heritability values in wheat (Al-Naggar 2015). Heritability ratio was used to determine the additives variance on genetic variance, heritability ratio on the weight of 100 seeds, number of seeds per pod, number of pods per bunch, number of pods per plant and yield per plant each $100 \%$, $99 \%, 99 \%, 90 \%$, and $51 \%$.

\section{Protein content}

Protein content has a variance of GCA values greater than the variance of SCA. The broad sense heritability and narrow sense heritability of the protein content of the seeds is included in the high category with each value of 0.918 and 0.745 (Syukut et al. 2010), according to the results of narrow sense heritability values in wheat (Al-Naggar 2015) narrow sense heritability of protein content was in the low category in all nitrogen treatments but in the broad sense heritability of protein content was in the high category The heritability ratio is used to determine the ratio between various additives variance from genetic variance, the ratio of narrow sense heritability and broad sense heritability of protein content was $81 \%$.
Table 3. Analysis of variance combining ability character weight 10 seed, number of seeds per pod, number of pods per bunch, number of pods per plant, and yield in cowpea

\begin{tabular}{llllll}
\hline SV & $\begin{array}{l}\text { W100S } \\
(\mathbf{g})\end{array}$ & SP & PB & PP & $\begin{array}{l}\text { Y } \\
(\mathbf{g})\end{array}$ \\
\hline REP & 1.31 & 1.37 & 0.01 & 58.69 & 46.3 \\
Cross & 5.59 & 4.41 & 0.07 & 72.61 & 88.64 \\
GCA & $28.29^{* *}$ & $20.88^{* *}$ & $0.16^{*}$ & $148.77^{\text {ns }}$ & $44.87^{\text {ns }}$ \\
SCA & $0.60^{\text {ns }}$ & $0.68^{\text {ns }}$ & $0.04^{\text {ns }}$ & $70.23^{\text {ns }}$ & $121.94^{\text {ns }}$ \\
Reciprocal & $1.49^{\text {ns }}$ & $1.55^{\text {ns }}$ & $0.07^{\text {ns }}$ & $44.53^{\text {ns }}$ & $72.86^{\text {ns }}$ \\
Residuals & 2.82 & 0.94 & 0.10 & 48.74 & 44.25 \\
\hline
\end{tabular}

Note: W100S: weight of 100 seed, PB: number of pods per bunch, PP: number of pods per plant, SP: number of seeds per pod: , Y: yield, ${ }^{*}$ significant at the 0.05 probability level, ${ }^{* *}$ significant at the 0.01 probability level, ${ }^{\mathrm{ns}}$ not significant, GCA:

General combining ability, SCA: Specific combining ability

Table 4. Analysis of variance combining ability protein content in cowpea

\begin{tabular}{ll}
\hline SV & PC \\
\hline REP & 1.90 \\
Cross & 5.26 \\
GCA & $15.06^{* * *}$ \\
SCA & $1.34^{\mathrm{ns}}$ \\
Reciprocal & - \\
Residuals & 1.29 \\
\hline
\end{tabular}

Note: Protein content: $\mathrm{PC},{ }^{*}$ significant at the 0.05 probability level, ${ }^{* *}$ significant at the 0.01 probability level, ${ }^{\mathrm{ns}}$ not significant, GCA: General combining ability, SCA: Specific combining ability

Table 5. Component of variance and heritability weigh of 100 seed, number of seeds per pod, number of pods per bunch, number of pods per plant, and yield per plant

\begin{tabular}{llllll}
\hline Component & SP & W100S $(\mathbf{g})$ & PB & PP & Y(g) \\
\hline$\sigma^{2}{ }_{\mathrm{e}}$ & 0.31 & 0.94 & 0.032 & 16.25 & 14.75 \\
$\sigma^{2} \mathrm{~g}$ & 20.81 & 28.23 & 0.153 & 142.00 & 33.18 \\
$\sigma^{2}{ }_{\mathrm{s}}$ & 0.22 & -0.20 & 0.004 & 32.13 & 63.80 \\
$\sigma_{\mathrm{r}}^{2}$ & 0.62 & 0.27 & 0.017 & 14.14 & 29.05 \\
$\sigma^{2}{ }_{\mathrm{A}}^{2}$ & 41.62 & 56.47 & 0.306 & 284.01 & 66.37 \\
$\sigma^{2} \mathrm{D}$ & 0.22 & -0.20 & 0.004 & 32.13 & 63.80 \\
$\mathrm{~h}^{2}{ }_{\mathrm{ns}}$ & 0.99 & 0.99 & 0.894 & 0.85 & 0.45 \\
$\mathrm{~h}^{2}{ }_{\mathrm{bs}}$ & 0.99 & 0.98 & 0.906 & 0.95 & 0.89 \\
$\mathrm{~h}^{2}{ }_{\mathrm{n} /}{ }^{2}{ }_{\mathrm{bs}}$ & 0.99 & 1.00 & 0.990 & 0.90 & 0.51 \\
\hline
\end{tabular}

Note: W100S: weight of 100 seed, PB: number of pods per bunch, PP: number of pods per plant, SP: Number of seeds per pod, Y: yield per plant, $\sigma^{2}$ e: environmental variance, $\sigma^{2} \mathrm{~g}$ : GCA variance, $\sigma^{2} \mathrm{~s}$ : SCA variance, $\sigma^{2} \mathrm{r}$ : reciprocal variance, $\sigma^{2} \mathrm{~A}$ : additive variance, $\sigma^{2} \mathrm{D}$ : dominant variance, $\mathrm{h}^{2} \mathrm{bs}$ : broad-sense heritability, $\mathrm{h}^{2} \mathrm{~ns}$ : narrow-sense heritability

Table 6. Component of variance and heritability protein content character

\begin{tabular}{ll}
\hline Component & PC \\
\hline$\sigma^{2} \mathrm{e}$ & 0.43 \\
$\sigma^{2} \mathrm{~g}$ & 1.96 \\
$\sigma^{2}{ }_{\mathrm{s}}$ & 0.91 \\
$\sigma_{\mathrm{r}}^{2}$ & - \\
$\sigma^{2} \mathrm{~A}$ & 3.92 \\
$\sigma^{2} \mathrm{D}$ & 0.91 \\
$\mathrm{~h}^{2} \mathrm{~ns}$ & 0.745 \\
$\mathrm{~h}^{2} \mathrm{bs}$ & 0.918 \\
$\mathrm{~h}^{2}{ }_{\mathrm{ns}} / \mathrm{h}^{2} \mathrm{bs}$ & 0.81 \\
\hline
\end{tabular}


Note: PC: protein content, $\sigma^{2} \mathrm{e}$ : environmental variance, $\sigma^{2} \mathrm{~g}$ :GCA variance, $\sigma^{2} \mathrm{~s}$ : SCA variance, $\sigma^{2}$ r:reciprocal variance, $\sigma^{2} \mathrm{~A}$ : additive variance, $\sigma^{2} \mathrm{D}$ : dominant variance, $\mathrm{h}^{2} \mathrm{bs}$ : broad-sense heritability, $h^{2} n s$ : narrow-sense heritability

\section{Discussion}

Inheritance of trait involves additive genes effect and non-additive genes effect can be known through the variance of general combining ability (GCA) and specific combining ability (SCA) (Falconer dan Mackay 1996). The inheritance of traits in self-pollinating plants usually uses the Griffing Diallel method with a random model because it is only to see how inheritance the observed traits different from crossing pollination plants which are more specifically to forming hybrid genotypes so that the traits used have been evaluated especially for traits that support high yields, for this study the diallel Griffing method was used to evaluate parents line and the combination of best crosses (Griffing 1956).

Diallel random model, analysis showing general combining ability significantly indicates that traits are more influenced by additive gene effect, the analysis that showing significant specific combining ability indicates traits are more influenced by non-additive gene effect. Traits that have a greater general combining ability variance than specific combining ability are thought to be more influenced by additive genes (Fasahat et al. 2016), the traits with general combining ability are indicated traits more influenced by additive gene effect, which is weight of 100 seed, number of seeds per pod and number of pods per bunch are different from the results obtained on peanuts (Neya et al. 2017) the weight of 100 seeds is influenced by the effects of non-additive genes Similar results were reported by Idahosa and Alika (2013) in cowpea for 100 characters of seed weight which were influenced by additive and non additive effects. The pods reported by Neya et al. (2017) were more influenced by the effects of additive genes obtained from the results of GCA / SCA ratios greater than 1 while in the Idahosa and Alika (2013) results obtained that the number of seeds per pod was influenced by the additive gene effect and the non-additive that can be predicted from significant value of the general combining ability and specific combining ability according to Medici et al. (2004) significant general combining ability indicates that at least one of the results of the crossing affected by the effects of additive genes while significant specific combining ability indicates that at least one of the elders affected by the effect of a non-additive gene or the observed traits affected by more than one locus.

The number of pods per plant and yield per plant did not obtain significant on all components, indicating that there was no difference between the lines of the plants. Seed protein content significant in general combining ability and not significant in specific combining ability indicate that character is influenced by additive gene effect, which is different from the results obtained by Idahosa and Alika (2013) in Phaseolus vulgaris L. for protein characters affected by additive and non-additive gene effect but in peanuts (Layrisse et al. 1980) protein content was influencing by general combining ability than specific combining ability even though there are few maternal effects.

Heritability values explain the genetic proportions of the phenotype. High heritability values indicate wide diversity of the characters, making it possible to make selections (Junaid et al. 2014). The value of heritability consists of broad sense of heritability and narrow sense of heritability. Broad-sense heritability is interpreted that a character is influenced by the dominant gene's effect while narrow sense heritability indicates a character influenced by additive gene effect. A character can be used as a character selection if it has a high value of narrow heritability because the possibility of the character will be inherited from the next generation (Sujiprihati et al. 2002).

In this study the value of broad sense heritability and narrow sense heritability are high categories because more than 50\% (Table 5 dan Table 6) (Syukur et al. 2010) on the character of 100 seeds weight, number of seeds per pod, number of pods per bunch, number of pods per plant and seed protein content so that the character has the potential to be used as character selection because it is controlled by additive gene effect (Sujiprihati et al. 2002) that supported by the $\mathrm{h}^{2}{ }_{\mathrm{ns}} / \mathrm{h}^{2}$ bs ratio (Table 5 and Table 6) which approaches $100 \%$ of these characters with the highest ratio of 100 seeds. The heritability ratio is one of the important parameters because it explains the proportion of variance additives to the total variance as stated by Saputra et al. (2014) if the value of the heritability ratio bigger or close to $100 \%$, then a character has a higher proportion of additives.

The results obtained provide information about the relationship between general combining ability and the value of heritability. The effect of general combining power is very important to develop pure line from the crosses, while the high heritability value is an indicator that has a high diversity character, will be effective to selection in the F2 generation until F6 generation use pedigree selection method. These results support breeding in cowpea, because cowpea is selfing-pollinated plants so that they will be more effective if developed with homozygous genetic arrangements. The higher the homozygosity of a genotype, the additive genes can be fixed. It is expected that with the fixation of additive genes it will be obtained by individuals with segregation that have higher protein content and yield components than the average value of the parent value, this phenomenon is transgressive segregation namely heterosis phenomenon in segregation of selfpollinated plants.

\section{ACKNOWLEDGEMENTS}

The author would like to thank PKHT (Center for Tropical Horticulture Studies) Bogor Agricultural Institute for the research grant analysis of the protein content provided. 


\section{REFERENCES}

Aghao RR, Nair B, Kalamkar V, Bainade PS. 2010. Diallel analysis for yield and yield contributing characters in Indian mustard ( Brassica juncea ). J Oilseed Brassica 1(July):75-78.

Aisya SI, Wahyuni S, Syukur M, Witono JR. 2016. The estimation of combining ability and heterosis effect for yield and yield components in tomato (Lycopersicon esculentum Mill.) at lowland. Ekin J Crop Breed Genet 2(1): 23-29.

Alam MK, Nath UK, Azad MAK, Alam MA, Khan AA. 2013. Genetics of yield and related traits in groundnut using diallel analysis. Bull Inst Trop Agr Kyushu Univ 36: 45-59.

Al-Naggar AMM, Shabana R, El-Aleem MMA, El-Rashidy Z 2015.Diallel analysis of wheat grain protein content and yield in F 1 and $\mathrm{F} 2$ generations under contrasting nitrogen conditions. Am Res J Agric 1(4):12-29.

Boukar O, Fatokun CA, Huynh BL, Roberts PA, Close TJ. 2016. Genomic tools in cowpea breeding programs: status and perspectives. Front Plant Sci 7: 1-13.

Buu, MyMy. 2003. UCLA nutrition bytes title golden rice: genetically modified to reduce vitamin a deficiency, benefit or hazard?. J Nutr Bytes 9(2):1-5.

Daryanto A, Sujiprihati S, Syukur M. 2010. Heterosis dan daya gabung karakter agronomi cabai (Capsicum annuum L.) hasil persilangan half diallel. J Agron Indones 38(2): 113-121.

Falconer DS, Mackay TFC. 1996. Introduction to Quantitative Genetics. Longman, Malaysia.

Fasahat P, Rajabi A, Rad JM, Derera J. 2016. Principles and utilization of combining ability in plant breeding. Biom Biostat Int J 4(1):1-24

Fürst P. 2009. Basics in clinical nutrition: proteins and amino acids. ESPEN 4(2): 62-65.

Ganefianti DW, Fahrurrozi F. 2018. Heterosis and combining ability in complete diallel cross of seven chili pepper genotypes grown in ultisol. Agrivita J Agric Sci 40(2):359-369.

Griffing B. 1956. Concept of general and specific combining ability in relation to diallel crossing system. Aust J Biol Sci 9:463-493.

Hayman BI. 1954. The theory and analysis of diallel cross. Genetics 39: 789-809.

Idahosa DO, Alika JE. 2013. Diallel analysis of six agronomic characters in Vigna unguiculata genotypes. Afr J Plant Breed 1(1): 1-7.
Jean BNT, Joseph MB, Antoine MN, Nicolas YN, Emmanuel Y. 2011. Genetic analysis of seed proteins contents in cowpea (Vigna unguiculata L. Walp.). Afr J Biotechnol 10(16): 3077-3086.

Jogloy S, Tula W, Kesmala T. 2005. Combining ability analysis and phenotypic correlation of nodule parameters and agronomic traits in peanut (Arachis hypogaea L). Songklanakarin J Sci Technol 27(2):213-220.

Junaid M, Raziuddin, Kanwal M, Umair M, Ahmed S, Ahmed N, Alizai AA, N. Bano. 2014. Traits in Brassica napus. J Mater Environ Sci 5(4): 1-15.

Layrisse A, Wynne JC, Isleib TG. 1980. Combining ability for yield, protein, and oil of peanut lines from South American centers of diversity. Euphytica 29(3): 561-570

Mbusa HK, Ngugi K, Olubayo FM, Kivuva BM, Muthomi JW, Nzuve FM. 2018. The Inheritance of yield components and beta carotene content in sweet potato. J Agric Sci 10(2):71-81.

Medici LO, Pereira MB, Lea PJ, Azevedo RA. 2004. Diallel analysis of maize lines with contrasting responses to applied nitrogen. J Agric Sci 142(5): 535-541.

Molina L. 2017. Development of advanced mutant lines of barley with higher mineral concentrations through radiation-induced mutagenesis in Perú am. Peruvian J Agron 1(1): 14-20.

Nair R, Mehta AK. 2014. Induced mutagenesis in cowpea [Vigna unguiculata (L.) Walp] var. Arka Garima. Indian J Agric Res 48(4):247-257.

Neya FB, Elise S, Koita K, Zagre BM, Sankara P. 2017. Diallel analysis of pod yield and 100 seeds weight in peanut (Arachis hypogaea L) using Griffing and Hayman methods. J Appl Biosci 116: 19-27.

Patel SP, Dhedhi KK, Bharodia PS, Joshi AK. 2010. Genetic analysis of pod yield and its attributes in vegetable cowpea. Int J Plant Sci 5:309312.

Saputra HE, Syukur M, Aisyah I. 2014. Combining ability and heritability estimation of tomato yield component in full diallel crosses. J Agron 42(3): 203-209. [Indonesian]

Singh RK, Chaudhary RD. 1979. Biometrical Methods in Quantitative Genetic Analysis. Kalyani Publishers, New Delhi.

Sujiprihati S, Saleh GB, Ali ES. 2002. Heritability, performance and correlation studies on single cross hybrids of tropical maize. Asian J Plant Sci 2(1): 51-57.

Syukur M, Sujiprihati S, Yunianti R, Undang. 2010. Diallel analysis using Hayman method to study genetic parameters of yield components in pepper (Capsicum annuum L). Hayati J Biosci 17(4): 183-188. 